\title{
DEVELOPMENT OF DIFFUSIVE DRYING PROCESS USING COMPRESSED DRY AIR IN PHARMACEUTICAL INDUSTRY
}

\author{
Regina Aryanti, Irvan Kartawiria*, Paulus Gunawan \\ Departemen Teknik Kimia/ Pharmaceutical Engineering, Swiss German University \\ Edu Town Kav EDU II.1, BSD, Tangerang 15339, Indonesia \\ Email: irvan.kartawiria@sgu.ac.id
}

\begin{abstract}
Most of drying processes applies excessive heat which damages heat sensitive material, including foods, pharmaceutical, neutraceutical substances, and herbal medicines. Drying approach is categorized into evaporative drying that utilize heat as driving force, and diffusive drying that uses vapor pressure difference to reduce moisture content. Diffusive drying requires media with very low vapor pressure, such as compressed dry air used in pharmaceutical industry. The objective of this research is to develop drying process based on diffusion principle pharmaceutical grade compressed dry air. Process development involves mathematical modeling based on diffusion principles, construction of equipment prototype, validation, and verification of the model using the prototype. Lactose granules (50 g and 70 g) were used as example. The drying process reduces lactose moisture content from $11.38 \%$ to $4.75 \%$ in 85 seconds at room temperature. Compressed dry air used at moisture content $0.0005 \%$ with flow rates of $1.47 \times 10^{-2}, 1.58 \times 10^{-2}$, and $1.67 \times 10^{-2} \mathrm{~m}^{3} / \mathrm{s}$ (operating pressure of $1.3,1.6$, and 1.8 bars). The diffusive drying model developed in this research has been successfully validated against physical behavior with accuracies of $84.24-99.61 \%$. It can be concluded that the compressed dry air in pharmaceutical industry is potential for diffusive drying process at room temperature.
\end{abstract}

Keywords: drying, diffusive, compressed air, model

\begin{abstract}
Abstrak
PENGEMBANGAN PROSES PENGERINGAN DIFUSIONAL DENGAN UDARA TEKAN KERING UNTUK INDUSTRI FARMASI. Kebanyakan proses pengeringan memberikan panas yang berlebihan, yang dapat merusak bahan-bahan peka panas seperti bahan-bahan pangan, farmasetika, nutrasetika, serta obat-obatan herbal. Pendekatan umum proses pengeringan dapat dibedakan menjadi pengeringan evaporatif yang memanfaatkan panas sebagai gaya pendorong, serta pengeringan difusional yang memanfaatkan perbedaan tekanan uap untuk mengurangi kadar air bahan umpan. Pengeringan difusional memerlukan media bertekanan uap sangat rendah untuk melepaskan air dari produk, seperti udara tekan kering, untuk penerapan di industri farmasi. Udara tekan di industri farmasi harus sesuai dengan standar ISO 8573.1 Class 1, yang mensyaratkan kelembaban sangat rendah. Tujuan penelitian ini adalah untuk mengembangkan proses pengeringan berdasarkan prinsip difusi, menggunakan udara tekan kering sesuai standar industri farmasi. Pengembangan melibatkan pemodelan matematik berdasarkan prinsip-prinsip difusi, pembangunan prototipe alat, validasi, dan verifikasi model menggunakan prototipe tersebut. Udara tekan kering memiliki kadar air 0,0005\% dengan laju alir divariasikan pada $1.47 \times 10^{-2} \mathrm{~m}^{3} / \mathrm{s}$, $1.58 \times 10^{-2} \mathrm{~m}^{3} / \mathrm{s}, 1.67 \times 10^{-2} \mathrm{~m}^{3} / \mathrm{s}$ (pada tekanan operasi 1,3, 1,6, dan 1,8 bar). Model pengeringan difusional yang dikembangkan berhasil divalidasi terhadap kelakuan nyata dengan akurasi 84.24 - 99.61\%. Dapat disimpulkan bahwa udara kering tekan berstandar industri farmasi dapat digunakan untuk proses pengeringan difusional pada temperatur ambien.
\end{abstract}

Kata kunci: pengeringan, difusional, udara tekan, model

*corresponding author 


\section{INTRODUCTION}

Drying is used widely in pharmaceutical industry to remove water or other solute contained in materials. Most of drying procedures applies excessive heat which can damage heat sensitive material, for instance foods, pharmaceutical, neutraceutical substances, herbs, spices and herbal medicines (Chua et al., 2003 ). Study shows that the concentration of $\beta$-carotene in carrot undergoing continuous drying decreased with drying time due to thermal degradation (Pan et al., 1999). The quality of cranberries using pulsed microwave vacuum drying along with one of the experiments resulted in the degradation of the quality of a heat-sensitive material (Gunasekaran, 1999). Phytochemicals which includes polyphenols are also known to be heat sensitive. Study shows that the highest content of plantamajoside, a type of polyphenols was obtained from lowest drying temperature (Zubair et al., 2011).

There are various methods that are commonly used to dry heat sensitive material, such as freeze dryers, spray dryers and high vacuum dryers (Devki Energy Consultancy, 2006). Nevertheless, these methods also have disadvantages (Ohtake et al., 2010; Chen et al., 2011; Moreira et al., 2009; Kompany et al., 1993).

Drying approach can be categorized into two types, which are evaporative drying and diffusive drying. Evaporative drying utilizes heat as the driving force while diffusive makes use of different vapor pressure as the driving force. Diffusive drying does not reflect temperature dependence. Drying process occur in different vapor pressure which migrating high vapor pressure to lower vapor pressure. By means of this basic principle, given that the drying air being used has very low vapor pressure, it can release vapor pressure without using heat in the process.

Compressed dry air in pharmaceutical industry is considered to be an option taking into account that it has to comply with the standard quality of ISO 8573.1 Class 1 (Wilkerson, 2008). The maximum dew point of water vapor allowed in the compressed dry air of this class is $-94^{\circ} \mathrm{F}$ or $-70^{\circ} \mathrm{C}$.

In the research of two dimensional model for mass and energy transport during drying assuming the process to be controlled by diffusion within the drying subject uses a stationary method as the product is placed in the dryer. The diffusion takes place from three surfaces in contact with the drying air. It is predicted to be more effective if diffusion drying takes place from around the individual particle. This can be achieved by making the material fluidized during drying process (Sun et al., 2005).

This research focused on the utilization of this abundantly available high-quality compressed air for the diffusive drying process. Although the quality of compressed air in pharmaceutical industry is interesting for exploration, the pressure available may limit the application. Therefore the design and operating parameters of effective diffusive drying process using pharmaceutical grade compressed dry air must be further developed and investigated to obtain a workable process.

In evaporative drying, the correlation between temperature and drying rate is proportional. However, for heat sensitive materials, high heat and mass transfer rates at the surface will result in overheating or overdrying of the material. This can leads to quality problems without major increase in the drying rates (Sun et al., 2005).

In diffusive drying, the main principle is removing the vapor from the material using diffusion (Or et al., 2007). The theory of water migration by diffusion is represented by the Fick's second law (Equation 1) which expressed in terms of moisture content gradient (Shokri et al., 2010).

$J_{A}=-D_{A B}\left(\frac{\partial C_{A}}{\partial Z}\right)$

In Equation (1), $J_{A}$ is the flux of diffusion relative to the molar average velocity of one component. Diffusivity or diffusion coefficient of component $A$ in solution in component $B$ is represented by $D_{A B}$. Diffusivity is a characteristic of a constituent and environment such as temperature, pressure, concentration, material state such as liquid, gas or solid, and the nature of other constituents.

Fick's law of diffusion as shown in Equation 1 involves several heat and mass transfer mechanism. The characterization of mass transfer phenomena typically by the determination of moisture diffusivity and moisture transfer coefficient (Hall adn Allison, 2010). The relationship of moisture diffusivity has been found in which diffusivity depends 
upon temperature and moisture content (Whitaker and Chou, 1983).

Drying coefficient is a parameter that indicates the drying capability of the solid material and has a direct effect on the moisture diffusivity. In the research of thermal diffusion of water vapor in porous material concludes that the sole significant transport potential for the diffusion of water vapor in porous materials is vapor pressure (Katherine, 2011). Vapor pressure gradients are responsible in the diffusion under nonisothermal conditions.

One of many critical factors that control diffusion rate is the contact surface area. As the surface contact area increases the volume available for diffusion will also increase thereby changing the concentration gradient within material. Concentration gradient affects diffusion because it changes the pressure forcing the moisture to diffuse. Surface area increases or decreases the volume available for diffusion, and thereby changes the concentration gradient. Concentration gradient affects diffusion because it changes the pressure forcing the substance or gas to diffuse. Consequently, the larger the surface area the larger concentration gradient and the higher drying rate will be.

Fluidization method is considered to be the best method in order to obtain excellent contact between the drying medium and the samples (Nokhodchi, 2005). High drying rates due to excellent gas-particle contact that leads to high heat and mass transfer (Chua et al., 2003). Mass transfer and heat transfer rates between particles and submerged objects are greatly enhanced in fluidized beds. In addition, rapid particle mixing allows uniformity in bed.

The factor of void fraction $(\varepsilon)$ has been incorporated into the model of fluidization condition, while we are calculating the minimum fluidization velocity. Initial void fraction used is 0.0036 , which is aligned with many literatures for loosely packed pharmaceutical excipient materials. The condition of fully fluidized is achieved at the experiment as all the compressed air pressure variable provide velocity significantly larger than minimum fluidization velocity according to $\bar{V}_{0 M} \approx\left[\frac{\Phi_{S} D_{p} g\left(\rho_{p}-\rho\right) \varepsilon_{M}^{3}}{1.75 \rho}\right]^{1 / 2}$ (Whitaker and Chou, 1983). Value of other coefficient such as $\boldsymbol{\Phi}_{\boldsymbol{s}}=0.75, \boldsymbol{\rho}_{\boldsymbol{p}}=1576 \mathrm{~kg} / \mathrm{m}^{3}$ are used based on the common characteristics of pharmaceutical excipients.

\section{METHOD}

Lactose granules (BratacoChem, Serpong) used was $50 \mathrm{~g}$ and $70 \mathrm{~g}$. Drying unit was constructed using fluidized chamber as model with the quick valves at the side port and stop nipple at the bottom port. The drying unit was Stainless Steel cylindrical body with $145 \mathrm{~mm}$ internal diameter and $475 \mathrm{~mm}$ total height, including conical shape bottom. The top closure was stainless steel plate, equipped with ports for air outlet and probes. The compressed dry air, produced by oil-free compressor (Ingersoll Rand, NIRVANA) was introduced to the unit from point-of-use outlet, connected through $8 \mathrm{~mm}$ diameter flexible pipe.

The flow of compressed dry air was set until pressure gauge showed 1.3, 1.6, or 1.8 bars. Measurement of temperature and relative humidity inside the vessel using thermo-hygrometer (Lutron, YK-90HT) was done every 5 s. Granule sample was taken with spatula via sampling port.The duration of drying was $0,5,10,15,25,45,65$, and 85 seconds. During those times, the compressed dry air setting was unchanged and left running throughout the experiment for steady volumetric flow rate. The samples then were stored in the tight container box with silica gel (PT. Brataco, Serpong). The repetition for experimental data was as shown.

The moisture content of granule was analyzed using moisture content analyzer (Sartorius, MC 45) in $110^{\circ} \mathrm{C}$ for 10 minutes. The result then was documented and analyzed.

\section{RESULT AND DISCUSSION Mathematical Modeling of Drying}

The mathematical model of drying heat sensitive material is made based on the equilibrium mass balance theory. The assumption in black box modeling is drying air in equals drying air out while the density of air coming in and out is not constant. Figure 1 describes the simplified schematic diagram of drying process.

Variable $F i\left(\mathrm{~m}^{3} / \mathrm{s}\right)$ is the input flow rate of the drying air, which comes from compressor. $X a(\%)$ is the moisture content of inlet drying air while $X o(\%)$ is the final moisture content after drying process. $X_{s o}(\%)$ on the other hand is the moisture content of 
the material out of the system and $X_{s i}(\%)$ is the moisture content of the material in the system. and $V b\left(\mathrm{~m}^{3}\right)$ is the volume of bulk material. The mathematical model is developed to find out relationship between the drying rates to the drying process parameter. The model is supposed to correlate drying rate as a function of mass (kg), flow input air $\left(\mathrm{m}^{3} / \mathrm{s}\right)$, and moisture content of initial air (\%) as shown in Equation 2 .

$\frac{d X}{d t}=f(m, F i, X a)$

The $\mathrm{H}_{2} \mathrm{O}$ mass balance equation is:

$\frac{d(X . V b) \rho_{l}}{d t}=\left(F i X_{H_{2} o}^{a}-F o X_{H_{2} o}^{o}\right) \rho_{g}$

$\frac{d X}{d t}=\left(\frac{F i X_{\mathrm{H}_{2} \mathrm{o}}^{a}}{V b}-\frac{F o X_{\mathrm{H}_{2} \mathrm{o}}^{o}}{V b}\right) \frac{\rho_{g}}{\rho_{l}}$

This correlation describes a non steady-state process where $\frac{\mathrm{Fo}_{\mathrm{H}_{2} \mathrm{o}}^{\mathrm{O}}}{\mathrm{Vb}}$ parties a function of diffusion. The relationship can be stated as in Equation 5.

$\mathrm{Fo}_{\mathrm{O}} \mathcal{X}_{\mathrm{H}_{2} \mathrm{O}}^{\mathrm{O}} \approx \mathrm{N}_{\mathrm{H}_{2} \mathrm{O}}$

The correlation can be elaborated using the principle of diffusions. Diffusion is a function of flux that can be written as follow (Balasubramanian, 2009):

$N_{\mathrm{H}_{2} \mathrm{O}}=k_{L} \Delta C_{\mathrm{H}_{2} \mathrm{O}}$

where

$\Delta C_{H_{2} \mathrm{O}}=\left(\mathcal{X}-\chi_{\mathrm{H}_{2} \mathrm{O}}^{a}\right) \frac{P}{R T}$

Where $\mathrm{P}$ is the total pressure, $\mathrm{T}$ is the air temperature and $\mathrm{R}$ is the individual gas constant or $\mathrm{R}_{\text {air }}$ which is $286.9 \mathrm{~J} / \mathrm{kg} \mathrm{K}$.

Therefore,

$N_{H_{2} \mathrm{O}}=k_{L}\left(X-\chi_{H_{2} \mathrm{O}}^{a}\right) \frac{P}{R T}$

Dimensional analysis of the process leads to the development of (5) into

$F_{o} X_{H_{2} \mathrm{O}}^{o}=N_{\mathrm{H}_{2} \mathrm{O}} A_{p} \frac{1}{\rho_{\mathrm{H} 2 \mathrm{O}}} M w_{\mathrm{H} 2 \mathrm{O}}$

Where $A p$ is the surface area of diffusions that can be estimated as the total surface area of entire particle in the bulk. $A p$ can be represented as (Batista et al., 2007):

$A p=\frac{6 m}{\phi_{s} \rho_{p} D_{p}}$

Therefore the completed model of diffusive drying process is represented as:

$\frac{d x}{d t}=\left(\frac{F i X_{H_{2} O}^{a}}{V b}-\frac{N_{H_{2} O} A_{p} M w_{H 2 O}}{\rho_{H_{2} O} V b}\right) \frac{\rho_{g}}{\rho_{l}}$

$\frac{d x}{d t}=\left(\frac{F i \chi_{H_{2} o}^{a} \rho_{b}}{m}-\frac{k_{L}\left(x-x_{H_{2} o}^{a}\right) 6 \rho_{b} P M w_{H 2 O}}{\rho_{H 2 O} \phi_{S} \rho_{p} D_{p} R T}\right) \frac{\rho_{g}}{\rho_{l}}(12)$

Equation 12 consists of 2 elements which are $\frac{\mathrm{Fi}_{\mathrm{H}_{2} \mathrm{O}}^{a} \rho_{b} \rho_{g}}{m \rho_{l}}$ corresponding to the flow while $\frac{k_{L}\left(x-x_{H_{2} O}^{a}\right) 6 \rho_{b} P M w_{H 2 O} \rho_{g}}{\rho_{H 2 O} \phi_{s} \rho_{p} D_{p} R T \rho_{l}}$ symbolize the diffusion in the surface wet material.

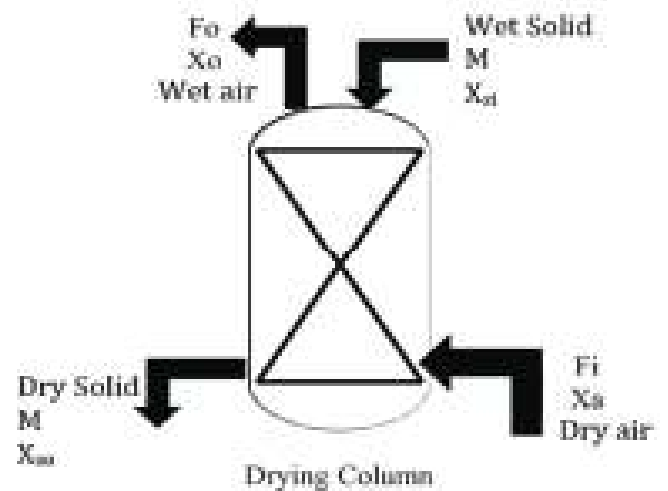

Figure 1. Schematic diagram of drying process

\section{Model Validation}

The model is validated to evaluate the applicability and conformance with actual physical and thermodynamic principles.

\section{Effect of Mass within Constant Flow Rate}

With constant flow rate when mass is increased, the drying rate should be decreased. This situation occurs since the mass increased the amount of moisture in bulk material will also increased thus resulting in the slower rate of drying.

Figure 2 shows the conformance of the behavior of model with this preposition. With $50 \mathrm{~g}$ mass, the time required to achieve lowest and stable moisture content of $3.25 \%$ is $155 \mathrm{~s}$. In contrast, the time required for $70 \mathrm{~g}$ to achieve lowest moisture content of $3.66 \%$ is $245 \mathrm{~s}$. This indicates that higher mass require 
higher time to dry material within the same flow rate.

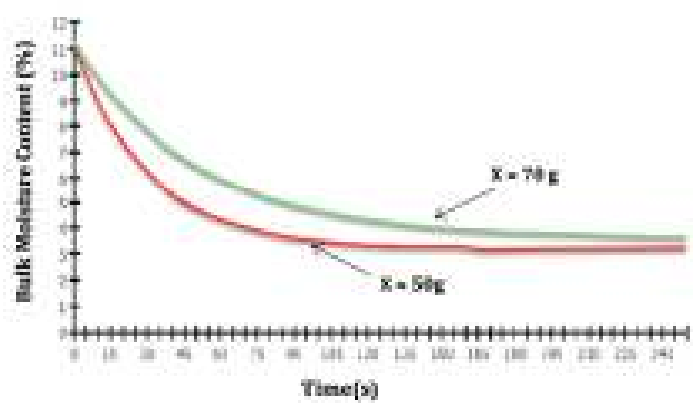

Figure 2. Bulk moisture content versus time under constant flow rate $1.47 \times 10^{-2}$ $\mathbf{m}^{3} / \mathbf{s}$

\section{Effect of Flow Rate within Constant Mass}

The pressure measured in the vesselis used to determine the volumetric flow rate of the compressed dry air. The volumetric flow rates used in this research were $1.47 \times 10^{-2}$ $\mathrm{m}^{3} / \mathrm{s}, 1.58 \times 10^{-2} \mathrm{~m}^{3} / \mathrm{s}$ and $1.67 \times 10^{-2} \mathrm{~m}^{3} / \mathrm{s}$.

Within constant mass, as the flow rate increase the moisture content within the material should diffuse faster than lower flow rate. In process with pressure of 1.3 bars the bulk moisture at $155 \mathrm{~s}$ is $3.25 \%$. In 1.6 bars the bulk moisture at the same time is $3.59 \%$ while with 1.8 bars the bulk moisture content is $3.81 \%$. This shows the behavior of system is in accordance with the mathematical model.

According to the drying model equation, air flow rate is proportional with the rate of drying. In Equation 12 can be seen that the pressure itself affect the diffusion rate as the pressure is proportional with the drying rate. Nevertheless, there is minus sign for diffusion element and this explained the reason why as pressure increase, the drying rate is decrease. As the flow rate increase, the increase of diffusion element magnitude is more dominant than flow element. Pressure also contributes in molecular diffusion.

Molecular diffusion is concerned with the movement of individual molecules through a substance by virtue of their thermal energy (Balasubramanian, 2009). Diffusion rate increased as the pressure decrease. This is due to the effect of collisions in the molecule. In lower pressure, diffusion can occur more thoroughly within granules due to non-erratic movement of particle and water vapor can diffuse more as a result of less pressure in the system.
Effect of $k_{L}$ within Various Mass and Constant Flow Rate

Mass transfer coefficient $\left(k_{L}\right)$ also plays a part in the drying rate and has a direct effect on moisture diffusivity.

$k_{L}=\left(\frac{6 D_{A B} \Gamma}{\pi \rho \delta L}\right)^{1 / 2}$

The factors affecting $k_{L}$ are molecular diffusivity $\left(D_{A B}\right), \Gamma$ or mass rate of flow per unit width, density of the air $(\rho)$, length of wetted wall tower $(L)$, and the thickness of a layer $(\delta)$. As the mass increase, the thickness of layer and the length of wetted wall increase thus resulting in the decrease of molecular diffusivity of material. The effect of predicted $k_{L}$ within various mass and constant flow rates is demonstrated in Figure 3.

The simulation shown with process with 50 grams material achieves end moisture content faster than 70 grams. The mass transfer coefficient $\left(k_{L}\right)$ estimated for 50 grams is $9.66 \times 10^{-3} \mathrm{Kg} / \mathrm{m}^{2} \mathrm{~s}$ while $\left(k_{L}\right)$ for 70 grams is $6.11 \times 10^{-3} \mathrm{Kg} / \mathrm{m}^{2} \mathrm{~s}$. The $k_{L}$ estimated for 50 grams is also higher than in 70 grams. The model validates the hypothesis of higher mass result in lower $k_{L}$. The consequence of lower $k_{L}$ is lower drying rate as $k_{L}$ is directly proportional to the drying rate.

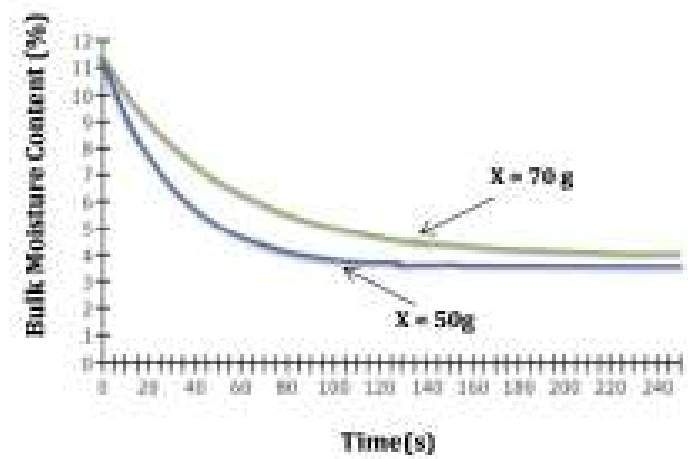

Figure 3. Bulk moisture content versus time under constant flow rate $1.58 \times 10^{-2}$ $\mathbf{m}^{3} / \mathbf{s}$

\section{Process Performance}

The suitability of utilization of pharmaceutical industry dry compressed air was evaluated through running the process at determined time. The data taken was from $0 \mathrm{~s}$ until 85 s. Figure 4 shows the differences between the estimated moisture content and the experimental result obtained. 


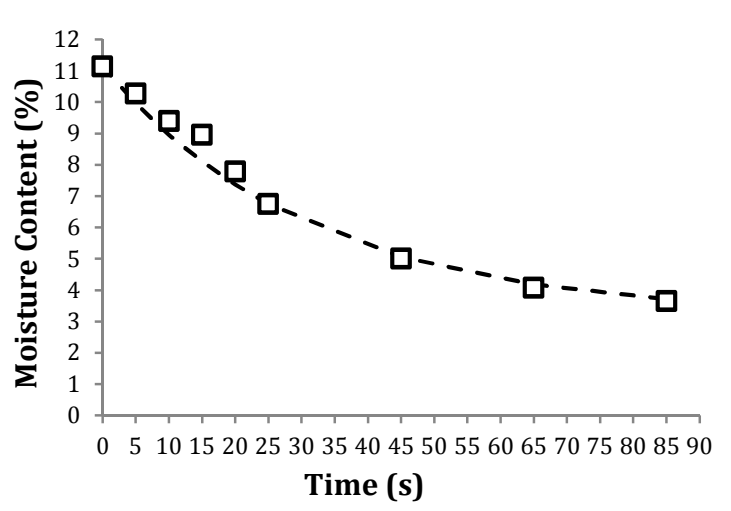

(a)

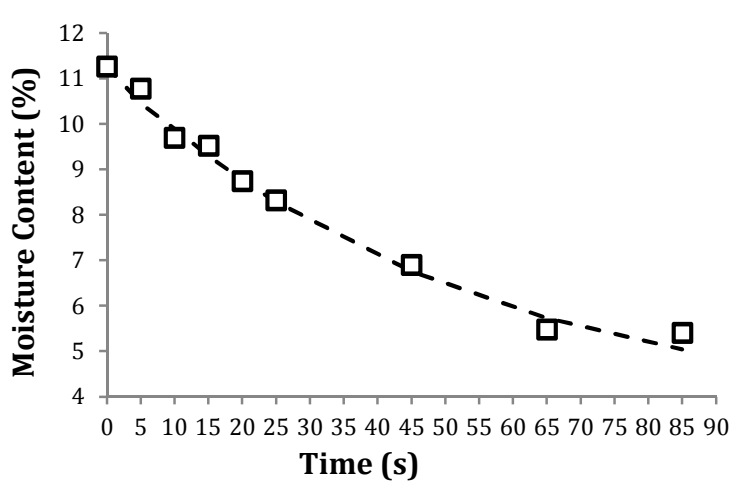

(b)

Figure 4. The comparison of model and experimental data ( $\square$ ) of bulk moisture content versus time under constant flow rate $1.47 \times 10^{-2} \mathrm{~m}^{3} / \mathrm{s}$, (a) $50 \mathrm{~g}$, (b) $70 \mathrm{~g}$

The percentage error between estimated value and measured moisture content under constant mass is shown in Table 1.

Table 1. Accuracy of Model at Constant Mass $50 \mathrm{~g}$

\begin{tabular}{ccccc}
\hline $\begin{array}{c}\text { Flow rate } \\
\left(\mathbf{m}^{3} / \mathbf{s}\right)\end{array}$ & $\begin{array}{c}\text { Pressure } \\
\text { (bar) }\end{array}$ & \multicolumn{2}{c}{$\begin{array}{c}\text { Moisture } \\
\text { Content }(\%)\end{array}$} & $\begin{array}{c}\text { Error } \\
\text { (\%) }\end{array}$ \\
\cline { 3 - 4 } & & Model & Exp & \\
\hline $1.47 \times 10^{-2}$ & 1.3 & 3.08 & 3.66 & 15.76 \\
$1.58 \times 10^{-2}$ & 1.6 & 4.06 & 4.10 & 0.83 \\
$1.67 \times 10^{-2}$ & 1.8 & 4.26 & 4.26 & 0.12 \\
\hline
\end{tabular}

The error is higher at lower flow rate, this might due to the condition of fluidization that may be different as estimated, which is prerequisite for effective diffusive drying process. Another point to measure process performance is the effect of mass transfer coefficient with regards to various masses. The differences between estimated values to actual measurement can be seen in Table 2 and Table 3.

Table 2. Accuracy of Model at Flow Rate

\begin{tabular}{cccc}
\multicolumn{3}{c}{$\mathbf{1 . 5 8 \times 1 0 ^ { - 2 } \mathbf { ~ m } ^ { 3 } / \mathbf { s }}$} \\
\hline Mass(g) & \multicolumn{2}{c}{$\begin{array}{c}\text { Moisture Content } \\
\text { (\%) }\end{array}$} & Error (\%) \\
\cline { 2 - 3 } & Model & Exp & \\
\hline 50 & 4.06 & 4.10 & 0.83 \\
70 & 5.40 & 5.50 & 1.73 \\
\hline
\end{tabular}

Although the volumetric flow rate of compressed dry air used in the process is capable of supplying fluid velocity higher than minimum fluidization velocity, the condition of fluidization is critical to the accuracy of process. Therefore when higher mass of powder is used in the process, the error is higher. The value however is still at acceptable level.

Table 3. Accuracy of Model at Flow Rate

\begin{tabular}{cccc}
\multicolumn{3}{c}{$\mathbf{1 . 6 7 \times 1 \mathbf { 1 0 } ^ { - 2 } \mathbf { ~ m } ^ { \mathbf { 3 } } / \mathbf { s }}$} \\
\hline Mass(g) & \multicolumn{2}{c}{$\begin{array}{c}\text { Moisture } \\
\text { Content (\%) }\end{array}$} & Error (\%) \\
\cline { 2 - 3 } & Model & Exp & \\
\hline 50 & 4.25 & 4.26 & 0.12 \\
70 & 5.58 & 5.60 & 0.39 \\
\hline
\end{tabular}

The evaluation of performance is important for the development of further process, as the pressure supplied by common pharmaceutical industry compressor is at 8-9 bars, and this will be the limiting factor of applicability. Fluidization condition that is essential for diffusive drying process may not be achieved at process with higher powder mass. The developed process however, is suitable for small-scale process, which many pharmaceutical industries require for their R\&D lab.

\section{CONCLUSION}

It can be concluded that the compressed dry air is suitable for diffusive drying process in small-scale operation using the fluidization chamber unit. The diffusive drying model developed in this research has been successfully validated against physical behavior. The accuracies of the model is $84.24-99.61 \%$ in various conditions (50 and $70 \mathrm{~g}$ of bulk material, flow rates of $1.47 \times 10^{-2}$ $\mathrm{m}^{3} / \mathrm{s}, \quad 1.58 \times 10^{-2} \mathrm{~m}^{3} / \mathrm{s}, 1.67 \times 10^{-2} \mathrm{~m}^{3} / \mathrm{s}$ ). The prototype developed based on the model is able to demonstrate effective drying process, 
lowering the moisture content from $11.38 \%$ to $4.75 \%$ in 85 seconds.

\section{ACKNOWLEDGEMENT}

The authors express sincerest gratitude to PT SOHO Industri Pharmasi for the support and providing compressed dry air.

\section{NOTATION}

A mass-transfer surface, $\mathrm{m}^{2}$

C concentration gradient

d differential operator diameter, $\mathrm{m}$

D molecular diffusivity, $\mathrm{m}^{2} / \mathrm{s}$

F flow, $\mathrm{m}^{3} / \mathrm{s}$

$\mathrm{k}$ mass transfer coefficients, mole $/ \mathrm{m}^{2} \mathrm{~s}$

m mass, $\mathrm{kg}$

$\mathrm{N}$ mass transfer flux at, and relative to, a phase boundary, mole $/ \mathrm{m}^{2} \mathrm{~s}$

$\mathrm{P}$ pressure, bar

$r \quad$ cross sectional area, $\mathrm{m}$

Q volumetric flow rate, $\mathrm{m}^{3} / \mathrm{s}$

$\mathrm{t}$ time, $\mathrm{s}$

$\mathrm{V} \quad$ volume, $\mathrm{m}^{3}$

$\mathrm{X}$ moisture content, \%

$\Gamma \quad$ mass rate of flow per unit width

$\Delta \quad$ difference

$\pi \quad$ phi number

$\rho$ density, $\mathrm{kg} / \mathrm{m}^{3}$

Фs sphericity

\section{Subscripts \\ a air \\ b bulk \\ i input \\ o output \\ p particle \\ w water}

\section{REFERENCES}

Chua, K. J.; Mujumdar, A. S.; Chou, S. K., Intermittent drying of bioproducts-an overview, Bioresource Technology, 2003, 90(3), 285-295.

Pan, Y. K.; Zhao, L. J.; Dong, Z. X.; Mujumdar, A. S.; Kudra, T., Intermittent drying of carrot in a vibrated fluid bed: Effect on product quality, Drying Technology, 1999, 17(10), 2323-2340.

Gunasekaran, S., Pulsed microwave-vacuum drying of food materials, Drying Technology, 1999, 17(3), 395-412.

Zubair, M.; Nybom, H.; Lindholm, C.; Rumpunen, K., Major polyphenols in aerial organs of greater plantain (Plantago major L.), and effects of drying temperature on polyphenol contents in the leaves, Scientia Horticulturae, 2011, 128(4), 523-529.

Devki Energy Consultancy, Best Practice Manual, 2006, http://www.energymanager training.com (akses 22 Juni 2012).

Ohtake, S.; Martin, R. A.; Yee, L.; Chen, D.; Kristensen, D. D.; Lechuga-Ballesteros, D.; Truong-Le, V., Heat-stable measles vaccine produced by spray drying, Vaccine, 2010, 28(5), 1275-1284.

Chen, G.; Wang, W.; Mujumdar, A. S., Theoretical study of microwave heating patterns on batch fluidized bed drying of porous material, Chemical Engineering Science, 2001, 56(24), 6823-6835.

Moreira, G. E. G.; Costa, M. G. M.; De Souza, A. C. R.; De Brito, E. S.; De Medeiros, M. F. D.; De Azeredo, H. M. C., Physical properties of spray dried acerola pomace extract as affected by temperature and drying aids, Food Science and Technology, 2009, 42(2), 641-645.

Kompany, E.; Benchimol, J.; Allaf, K.; Ainseba, B.; Bouvier, J. M., Dehydration kinetics and modelling, Drying Technology, 1993, 11(3), 451-470.

Wilkerson, Wilkerson Compressed Dry Air, 2008, http://www.wilkersoncorp.com/ catalog/ FRL-SIF-618_CompressedAirDrying. pdf (akses 22 Juni 2012).

Sun, L.; Islam, M. R.; Ho, J. C.; Mujumdar, A. S., A diffusion model for drying of a heat sensitive solid under multiple heat input nodes, Bioresource Technology, 2005, 96(14), 1551-1560.

Or, D.; Lehmann, P.; Shokri, N., Characteristic lengths affecting evaporation from heterogeneous porous media with sharp textural boundaries, Estudios de la Zona No Saturada del Suelo, 2007, 8, 1-8.

Shokri, N.; Lehmann, P.; Or, D., Evaporation from layered porous media, Journal of Geophysical Research: Solid Earth (19782012), 2010, 115(B6).

Hall, M. R.; Allinson, D., Evaporative drying in stabilised compressed earth materials using 
Development of Diffusive Drying Process Using Compressed Dry Air (R. Aryanti, et al.)

unsaturated flow theory, Building and Environment, 2010, 45(3), 509-518.

Whitaker, S.; Chou, W. T., Drying granular porous media - Theory and experiment, Drying Technology, 1983, 1(1), 3-33.

Katherine, A. M. J., Optimization of the Drying Process of Tea Produced from Butterfly Pea Petal, Tesis, Swiss German University, Tangerang, 2011.
Nokhodchi, A., Effect of moisture on compaction and compression, Pharmaceutical Technology, 2005, 6, 46-66.

Balasubramanian, V., Drying of Wet Materials: Convection Versus Diffusion Drying, Indian Institute of Technology, Madras: 2009.

Batista, L. M.; da Rosa, C. A.; Pinto, L. A., Diffusive model with variable effective diffusivity considering shrinkage in thin layer drying of chitosan, Journal of Food Engineering, 2007, 81(1), 127-132. 